\title{
A MODEL FOR ANALYZING THE IMPACT OF TOTAL QUALITY MANAGEMENT AND NON-FINANCIAL PERFORMANCE ON FINANCIAL PERFORMANCE OF HEALTHCARE INSTITUTIONS
}

\author{
*Merve TARIM \\ **Gulin Idil SONMEZTURK BOLATAN \\ *Istanbul Commerce University, Turkey \\ **Alanya Alaaddin Keykubat University, Turkey
}

\begin{abstract}
This study's main aim is to define total quality management's critical factors in the healthcare sector and to measure those factors' effects on business performance of hospitals in Turkey. Hospitals' performance is measured using subjective measures based on how hospitals' managers perceive how their organizations perform according to the competition. Partial least squares analysis technique was used to investigate the relationship between TQM practices and business performance. Analysis of the data from 50 hospitals revealed that TQM practices influence financial performance indirectly by influencing nonfinancial performance.
\end{abstract}

Keywords: Hospital Management, Total Quality Management, Business Performance, Partial Least Squares

\section{Introduction}

The service sector approximately accounts for 60 to 70 percent of the total worldwide GNP (Franklin, 1997). In the contemporary society, the service sector is expected to increase in importance due to the extraordinary growth of the sector. (Yavas et al., 1997;Camison, 1996;Bates et al., 2003;Zehir S., 2016) The basic concept of service management has changed. Two of the main changes include: (a) a shift from an interest in the internal consequences of performance (e.g., internal efficiency - productivity of labor and profits) to an interest in the external consequences (e.g., consumer behavior- customer satisfaction, loyalty), and (b) a shift from a focus on structure to a focus on process. In recent years, the health sector is one of the fastest growing industries in the service sector. Despite the fact that many hospitals offer the same type of services, except for a few specialized hospitals, the level of service quality throughout the hospital varies considerably. To acquire the perfect service, hospitals should work for zero defects and must keep every customer that the company can serve profitably to improve their service delivery system's quality. (Lim and Tang, 2000). Customer retention in the healthcare sector refers to customers' preference for the same hospital if and when the need arises for themselves or for their family members.

This study's aim is to define total quality management's crucial factors in the health sector and to measure the impact of crucial factors of total quality management on non-financial and financial performance. This study differs from earlier studies in several aspects. First, we investigate the relationship between quality practices and financial performance in healthcare industry in Turkey. Second, we consider mediation effects of quality practices on financial performance via their effects on non-financial performance. Finally, we use Partial Least Squares (PLS) method to solve structural equation model.

The remainder of this paper is organized as follows. The next section presents the literature review that helps to underpin the research framework and sets out the study's hypotheses. The research methodology is presented in the third section. Analysis and Results are in section four followed by summary and conclusion.

\section{Theoretical Background And Hypotheses}

Although there is a rich spectrum of research in the literature on total quality management, there is not a common definition of quality. Garvin, Crosby, Juran, Deming, Feigenbaum and Ishikawa (Kanji and 
Wallace, 2000) have described total quality management's concept in several ways. Total quality management can be defined as an organizational culture that commits resources to customer satisfaction through continuous improvement in products/services provided. This culture varies among countries and industries. In addition, it has essential principles which can be implemented to secure reduced costs, greater market share and increased profits (Kanji and Wallace, 2000). Moreover, management awareness of the total quality management's role in firm performance is stimulated by benchmarking which seeks, studies, implements and improves on best practices (Zairi and Youssef, 1995).

Various studies have been carried out to define total quality management's critical factors in the literature. As a result, different measurement instruments were developed such as Malcolm Baldrige Award, EFQM (European Foundation for Quality Management), and the Deming Prize Criteria (Powell, 1995). Based on these studies, a wide range of management techniques, approaches, and systematic empirical investigation have been developed (Saraph et al., 1989;Flyyn et al., 1994;Flyyn et al., 1995;Anderson et al., 1994;Black and Porter, 1996;Wilson and Collier, 2000;Flynn and Saladin, 2001;Benson et al., 1991;Samson and Terziovski, 1998;Ahire et al., 1996).

Performance measurement is significant for an organization's optimum management. Deming declares that, measurement of performance is a prerequisite for improvement (Deming, 1986). Hence, to improve the performance of the organization, one needs to define the total quality management standard and measure their effect on business performance (Madu et all., 1996;Zehir S., 2016;Gadenne and Sharma, 2002;Powel, 1995;Fynes and Voss, 2001). Traditionally, financial metrics were used to indicate business performance such as profit, revenue growth, earnings, and market share. (Kurt\& Zehir, 2016) However, as Kaplan and Norton underlined, financial indicators are measures of past performance only, and they may not be relied upon exclusively to determine future business performance (Kaplan and Norton, 1996).

Inclusion of non-financial indicators in the traditional performance measurement system can overcome this shortcoming. TQM has become an important tool for improving the organizational performance in the healthcare sector as indicated by a multitude of studies (McAlexander and Keldenberg, 1994; Eggli and Halfon, 2003;Kunst and Lemmink, 2000;Kenagy and Berwick, 1999;Butler and, Leong, 2000; Yasin et all., 1998;Li, 1998;Yang, 2003;Nwabueze and Kanji 1997;Zabada et all., 1998;Hansson and Eriksson, 2002;Sadikoglu\& ; 2010).

The present study aims to contribute to this proliferating body of information. In this study, we develop a structural equation model to measure the impact of quality practices' crucial factors on financial performance by considering both direct and indirect effects, via the impact on non-financial performance. We utilize partial least squares method to evaluate four research hypotheses for the healthcare sector in Turkey. Each hypothesis represents a relationship between the constructs in the model as represented in Figure 1. These hypotheses are:

H1: Total quality management criteria have a strong influence on non-financial performance in hospitals.

$\mathrm{H} 2$ : Total quality management criteria have a weak and direct influence on financial performance in hospitals.

H3: Non-financial performance criteria have a strong and direct influence on financial performance in hospitals.

H4: Non-Financial Performance plays a mediating role between Total quality management and Financial Performance. This hypothesis will hold if hypotheses 1 and 3 hold. 


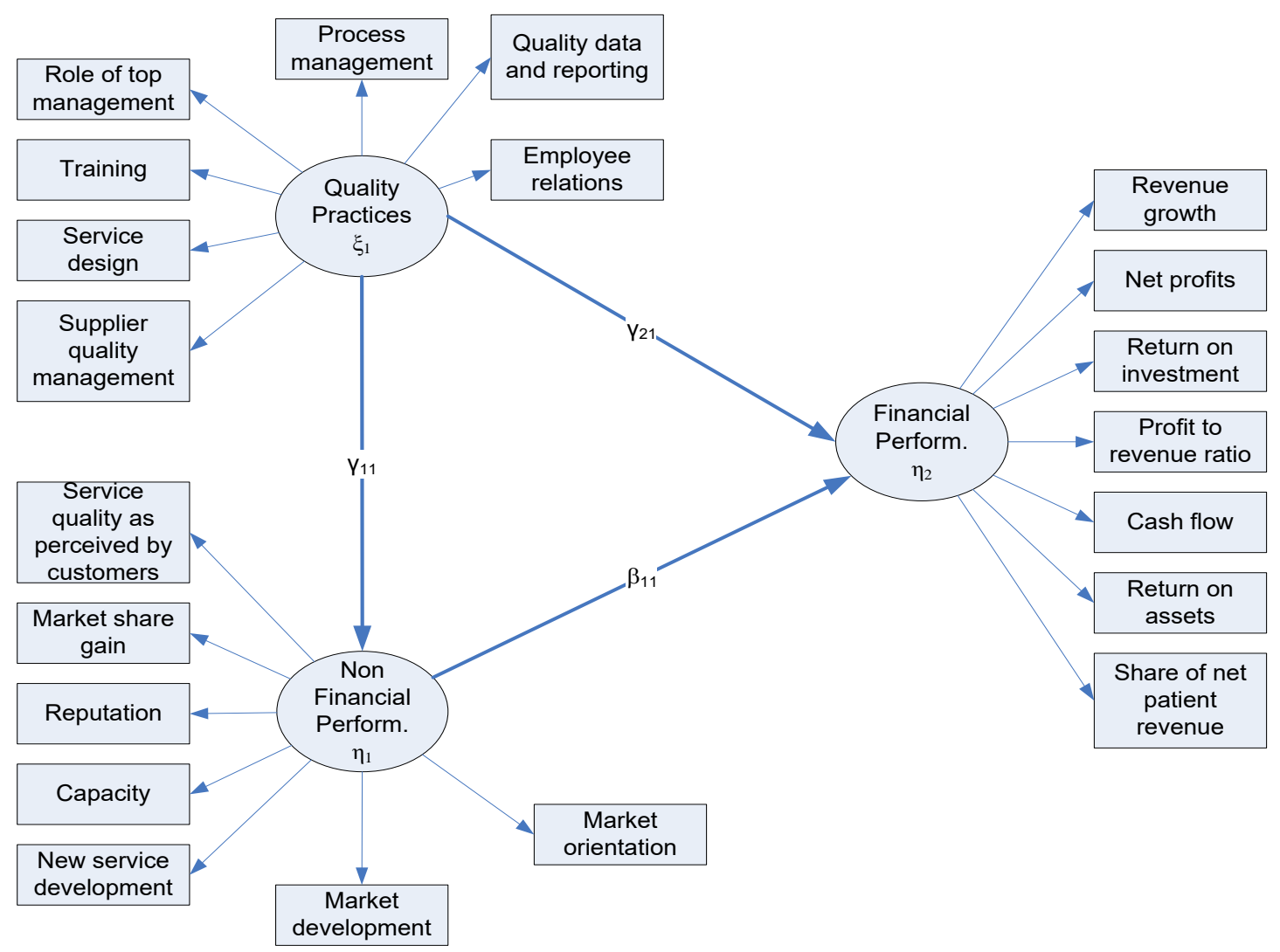

Figure 1 The Structural Model

Jacop, Madu and Tang provide theoretical support in their study for the above hypotheses. They indicate that total quality models, such as Malcolm Baldrige Award Models, need very expensive use of financial and other resources without contaminant return on investment. Hence, their critics conclude that investment in quality practices might lead to a decrease in financial performance in the short run. Therefore, total quality management is a strong predictor of long-term survival through their influence on non-financial performance metrics and a leading indicator of future profitability (Jacob et al., 2004;Madu et al., 1996).

\section{Methodology}

Private hospitals in Anatolia side of Istanbul/Turkey were selected to evaluate the impact of TQM variables on financial performance. A questionnaire was distributed to the Chief Administrative Officers of a universe of 61 private hospitals to collect the data. Data from 50 questionnaires, comprising a response rate of $82 \%$ were used in the subsequent analysis.

We used the instrument developed by Jayant V., Saraph, P., Roger G. Schroeder and George Benson, adapted by Raju and Lonial with the aim of defining total quality management's crucial factors in a business unit environment. Minor modifications were made in this instrument, in its final form; the questionnaire consisted of 43 items for 7 critical factors. Considering the well-established, empirical and conceptually strong nature of the framework from which the survey instrument was derived, its content validity is satisfactory.

The questionnaire's original language was English. It was translated into the local language (Turkish). Each item was rated on a five-point Likert scale, ranging from "very low" to "very high". The questionnaire was pre-tested several times to ensure that the wording, format, and sequencing of questions were appropriate. Total quality management, non-financial performance, and financial performance were measured using judgmental measures based on managers' perceptions of how the organization was performing on multiple indicators of each construct. Occasional missing data on 
variables were handled by replacing them with the mean value (Albaum et al., 2002). The questionnaire is given in Appendices A and B.

\section{Analysis And Results}

For the analysis of data, we followed a two-step approach:

1. Determination of the crucial factors of the total quality management.

2. Estimation of the structural equation model using PLS.

\section{Determining critical factors of TQM;}

We used seven Factors for quality practices by combining related variables into a single composite measure. There are two reasons why a composite model for the TQM block was used in this study. First, to conserve the degrees of freedom for the analysis (a sample size of 50), the indicators for each construct related to total quality management were represented by a single composite indicator as opposed to using all the individual indicators in the analysis. Thus each factor is derived by taking a weighted average of the items by using an equal weighting scheme. For example, we derived the first factor, role of top management, by taking the average score of the first nine variables. Next six factors are derived in a similar fashion. These factors are: training, product or service design, supplier quality management, process management, quality data and reporting, and employee relations.

\section{Unidimensionality and convergent validity of Summated Factors related to TQM}

For unidimensionality and convergent validity analysis, confirmatory factor analysis (CFA) was used in place of exploratory factor analysis (EFA). Mulaik (1972) provides a strong argument in favor of performing confirmatory factor analysis by suggesting that the major disadvantage of pure EFA lies in the difficulty involved in interpreting the factors. Implementing CFA method within Lisrel framework "allows the specification of measurement errors within a broader context of assessing measurement properties and describes a causal indicator model where the operational indicators are reflective of the unobserved theoretical construct". (Venkatraman, 1989).

In this study, seven summated factors were established: role of top management, training, product or service design, supplier quality management, process management, quality data and reporting, and employee relations.

Role of Top Management: Nine items defining role of top management dimension were subjected to CFA using AMOS computer program. Model shows GFI=0.92, AGFI=0.79, Chi-square=21.096 with 17 degrees of freedom, $(p<0.222)$, which is considered to be a good fit. Similar analysis was performed for the other six dimensions of total quality management.

\begin{tabular}{|l|c|c|c|c|c|c|c|c|}
\hline Dimension & $\begin{array}{c}\text { Number of } \\
\text { indicators }\end{array}$ & $\begin{array}{c}\text { Chi- } \\
\text { Square }\end{array}$ & df & P-Value & GFI & AGFI & CFI & TLI \\
\hline Role of Top Management & 9 & 21.096 & 17 & 0.222 & 0.92 & 0.79 & 0.98 & 0.97 \\
\hline Training & 4 & 2.525 & 1 & 0.112 & 0.975 & 0.755 & 0.99 & 0.93 \\
\hline Service Design & 5 & 5.886 & 4 & 0.208 & 0.957 & 0.84 & 0.98 & 0.97 \\
\hline $\begin{array}{l}\text { Supplier Quality } \\
\text { Management }\end{array}$ & 4 & 4.075 & 2 & 0.130 & 0.964 & 0.822 & 0.98 & 0.943 \\
\hline Process Management & 6 & 6.752 & 6 & 0.344 & 0.96 & 0.859 & 0.996 & 0.99 \\
\hline $\begin{array}{l}\text { Quality Data and } \\
\text { Reporting }\end{array}$ & 8 & 11.630 & 10 & 0.311 & 0.946 & 0.806 & 0.995 & 0.987 \\
\hline Employee Relations & 7 & 5.224 & 6 & 0.515 & 0.971 & 0.863 & 1 & 1 \\
\hline
\end{tabular}




\section{Table 1. Initial Confirmatory Factor Analysis Results}

Table 1 summarizes the results of assessments for unidimensionality for seven dimensions. It provides the following model statistics for the assessment of goodness-of-fit: The $\chi^{2}$ statistics, its associated degrees of freedom, p-value of significance, GFI, AGFI CFI, and Tucker-Lewis index. One can conclude that each of the seven dimensions achieves unidimensionality and convergent validity at mono-method level of analysis.

\section{Internal consistency of operationalization (Reliability)}

The results of unidimensionality do not provide a direct assessment of construct reliability, thus Cronbach's alpha coefficient as a measure of reliability was employed. The Cronbach's alpha measure of reliability for the seven factors were 0.92 for factor $1,0.91$ for factor 2, 0.89 for factor 3, 0.88 for factor 4 , 0.87 for factor 5, 0.79 for factor 6 , and 0.90 for factor 7. Cronbach's alpha measure for all factors are above the traditional acceptable value of 0.70 as suggested by Nunnaly (1978). As a result, this establishes the internal consistency of the dimensions being studied and is reliable for this research.

\section{Unidimensionality tests of blocks in the path model}

A causal modeling approach represented the constructs and tested the hypotheses. The key promises of the testable hypotheses in this study depend on the validity of the measurement properties of the three blocks. Figure 1 show the causal model studied in this paper.

In this model, since all manifest variables reflect their related latent variables, a reflective representation is more appropriate than a formative one. The validity and reliability of three reflective constructs were assessed by checking unidimensionality of each block using three tools: principal component analysis, Cronbach's alpha and Dillon-Goldstein's $\rho$ (Chin, 1998). As shown in Table 1, all of the Cronbach's alpha values met the minimum criterion alpha value of 0.70 . According to the principal component analysis, since the first eigenvalue score of the correlation matrix of the manifest variables of each construct is larger than one, and the second one is smaller than one each construct was considered as unidimensional. Similarly, Dillon-Goldstein's $\rho$ analysis provides $\rho$ values above 0.70 for each construct supporting unidimensionality.

\begin{tabular}{|c|c|c|c|c|c|}
\hline Block & $\begin{array}{c}\text { Number of } \\
\text { Indicators }\end{array}$ & Cronbach Alpha & $\begin{array}{c}\text { Dillon- } \\
\text { Goldstein's } \boldsymbol{\rho}\end{array}$ & $\begin{array}{c}\text { First } \\
\text { Eigenvalue }\end{array}$ & $\begin{array}{c}\text { Second } \\
\text { Eigenvalue }\end{array}$ \\
\hline TQM & 7 & 0.9367 & 0.9495 & 4.8621 & 0.5257 \\
\hline NONFIN & 7 & 0.9279 & 0.9458 & 4.3771 & 0.5572 \\
\hline FIN & 6 & 0.9069 & 0.9322 & 4.1478 & 0.7459 \\
\hline
\end{tabular}

\section{Table II. Unidimensionality check of the blocks Structural equation modeling;}

As mentioned earlier, we utilized partial least squares (PLS) approach to test the hypothesized relationships among the blocks. PLS procedure, developed by Wold (Wold, 1973), (Wold, 1975), (Wold, 1985) uses two stage estimation algorithms to obtain weights, loadings, and path estimates. In the first stage an iterative scheme of simple and/or multiple regressions contingent on the particular model is performed until a solution converges on a set of weights used for estimating the latent variables scores. The second stage involves the non-iterative application of PLS regression for obtaining loadings, path coefficients, mean scores and location parameters for the latent and manifest variables. For calculating PLS procedure Spad Decisia V56 statistical data analysis software was employed (LohmLoller, 1989), (Tenenhaus, 2004), (Fornell and Cha, 1994), (Tenenhaus et al., 2005).

\section{Outer model estimation}

Outer model, also known as a measurement model, links the manifest variables to their latent variables. The outer model estimation results are provided in Table 2. We find that correlations between the manifest variables and their related latent variables are very satisfactory. 
Journal of Global Strategic Management | V. 12 | N. 1 | 2018-June | isma.info | 067-080 | DOI: 10.20460/JGSM.2018.262

\begin{tabular}{|c|c|c|c|c|}
\hline $\begin{array}{l}\text { Latent } \\
\text { variable }\end{array}$ & $\begin{array}{c}\text { Manifest } \\
\text { variable }\end{array}$ & $\begin{array}{l}\text { Outer } \\
\text { weight }\end{array}$ & Correlation & Communality \\
\hline \multirow{7}{*}{ TQM } & TQM1 & 0.1940 & 0.8046 & 0.6473 \\
\hline & TQM2 & 0.1959 & 0.9135 & 0.8344 \\
\hline & TQM3 & 0.1759 & 0.8951 & 0.8011 \\
\hline & TQM4 & 0.1348 & 0.8327 & 0.6934 \\
\hline & TQM5 & 0.0874 & 0.7964 & 0.6343 \\
\hline & TQM6 & 0.2005 & 0.8509 & 0.7241 \\
\hline & TQM7 & 0.2054 & 0.8558 & 0.7324 \\
\hline \multirow{7}{*}{$\mathrm{NF}$} & NF1 & 0.1799 & 0.7671 & 0.5884 \\
\hline & NF2 & 0.2160 & 0.9030 & 0.8153 \\
\hline & NF3 & 0.1257 & 0.8248 & 0.6803 \\
\hline & NF4 & 0.1409 & 0.7998 & 0.6396 \\
\hline & NF5 & 0.2129 & 0.9296 & 0.8641 \\
\hline & NF6 & 0.1965 & 0.8914 & 0.7946 \\
\hline & NF7 & 0.1824 & 0.7227 & 0.5223 \\
\hline \multirow{6}{*}{ FP } & $\mathrm{F} 1$ & 0.2243 & 0.8233 & 0.6778 \\
\hline & $\mathrm{F} 2$ & 0.2454 & 0.9497 & 0.9020 \\
\hline & F3 & 0.1966 & 0.7826 & 0.6124 \\
\hline & $\mathrm{F} 4$ & 0.1946 & 0.8785 & 0.7718 \\
\hline & F5 & 0.1728 & 0.8221 & 0.6758 \\
\hline & F6 & 0.1615 & 0.6861 & 0.4707 \\
\hline
\end{tabular}

\section{Table III Outer model estimation results}

A communality measure, which is also R-square value, is the squared correlation between the manifest variable and its own related latent variable. It measures the capacity of the manifest variables to describe the related latent variable. Communality measure is expected to be higher than 0.60 for each manifest variables. In this application communality scores show that the manifest variables are very capable for estimating the change in related latent variable.

\section{Inner model estimation}

As shown in Figure 1, four main hypotheses were tested for this model. We provided estimation results for the inner model in Table IV. 


\begin{tabular}{|l|l|l|l|}
\hline Model & $\mathbf{R}^{2}$ & P-Value & $\begin{array}{l}\text { Bootstrap Estimated } \\
\text { Coefficients }\end{array}$ \\
\hline$\eta 1=2.535+0.539 \xi 1+\zeta 1$ & 0.2915 & 0.0001 & 0.533 \\
\hline$\eta 2=0.588+0.050 \xi 1+0.765 \eta 1+\zeta 1$ & 0.6300 & $\begin{array}{l}0.6312 \text { (for } \xi 1) \\
0.0000 \text { (for } \eta 1)\end{array}$ & $\begin{array}{l}0.048 \text { (for } \xi 1) \\
0.760 \text { (for } \eta 1)\end{array}$ \\
\hline$\eta 2=2.528+0.050 \xi 1+0.413 \xi 1+\zeta 1$ & 0.6300 & $\begin{array}{l}0.0000 \\
\text { (for indirect effect of } \xi 1 \text { ) }\end{array}$ & \\
\hline
\end{tabular}

Table IV Inner Model Results with Bootstrap Estimation

The first model looks at the relationship between non-financial performance and TQM. TQM explains about 29 percent of the variation in non-financial performance. TQM has a significant influence on nonfinancial performance with a coefficient value of 0.539 . The second model covers the second and third hypotheses. This model evaluates the impact of TQM and non-financial performance on financial performance. According to the overall model, TQM and non-financial performance explain approximately 63 percent of the variation in financial performance. Since the $t$ value is 0.483 , we reject the second hypothesis $(\mathrm{H} 2)$. This indicates that TQM does not have a direct influence on financial performance. For the third hypothesis $(\mathrm{H} 3)$, t value (7.258) is significant at the 0.01 levels, indicating that non-financial performance has a strong influence on financial performance. Similarly, we found that TQM has a significant indirect impact on financial performance (H4). Therefore, this result indicates that there is a significant relationship between TQM and Financial Performance through the mediation role of Non-Financial Performance (H4). Sobel test result shows that there is a significant $(\mathrm{p}<0.001)$ support for H4. Figure 2 provides the graphical representation of the structural model.

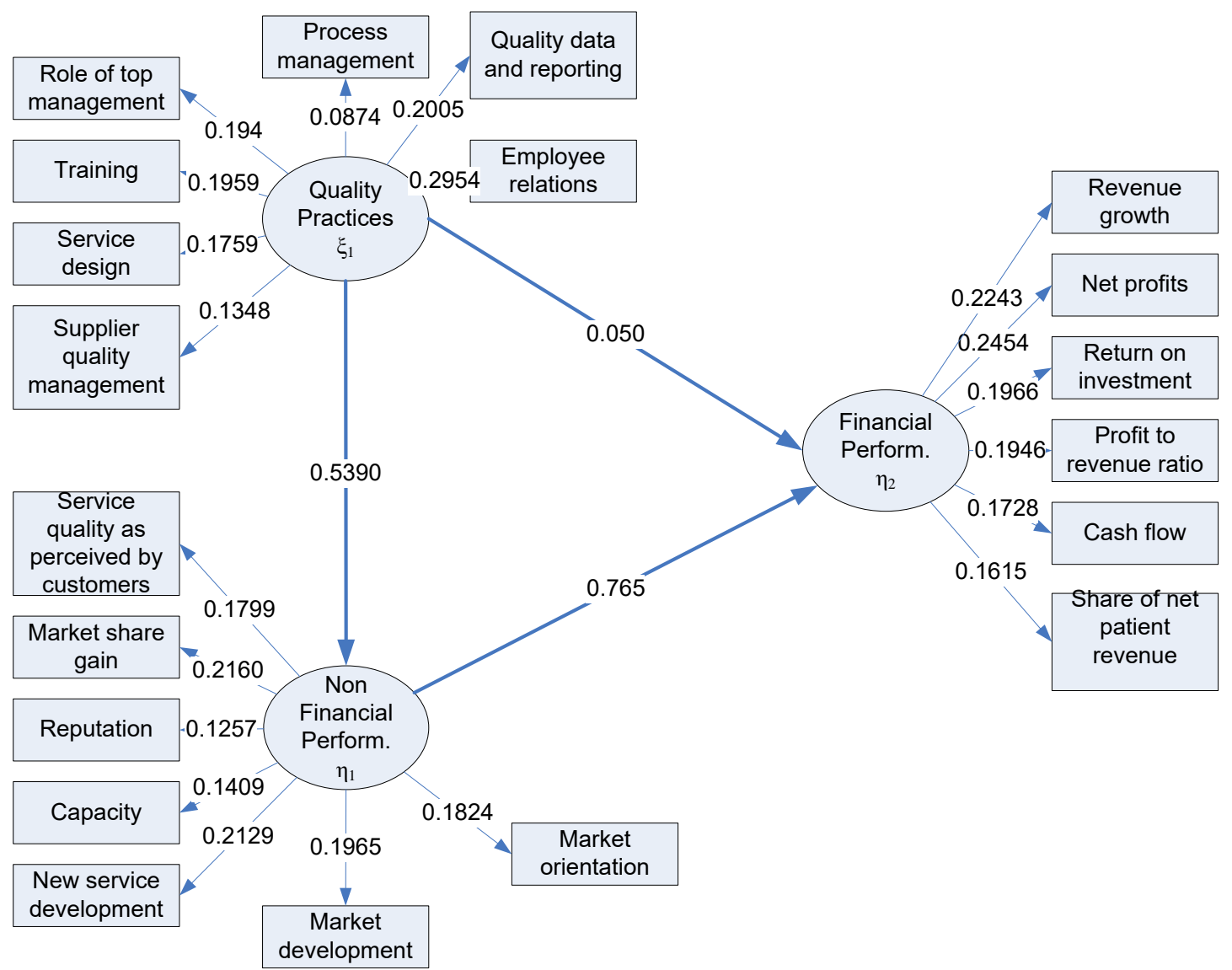

Figure 2 Path Model 
After the parameter estimation, we used bootstrapping to confirm the robustness of our findings. 1000 Bootstrap samples are built by resampling with replacement from the original sample. In the last column of Table III we provided summary results for bootstrapping. The bootstrap estimated coefficients of inner model are very close to the ones estimated using PLS.

\section{Summary And Conclusions}

In this study, we provided some evidence that TQM practices do not have direct influence on financial performance in the healthcare sector. However, by considering the indirect route through non-financial performance, we showed that TQM practices have a positive influence on financial performance. Lack of observable direct relationship between financial performance and TQM practices may lead to a suboptimal resource allocation toward quality practices. However, our interviews/data showed that hospital management recognize the importance of quality management by investing significant resources in transcribing and performing TQM programs to improve performance.

On the other hand, any hospitals in our sample do not have a quality department indicating that they may not be fully recognizant of the impact of TQM practices on financial performance. Using equations in appendix $\mathrm{C}$, index scores for TQM practices, non-financial performance and financial performance were found as 39.94, 58.65 and 57.22, respectively. The lowest index value for TQM practices can be attributed to "awakening" stage in the hospital sector as described by Crosby (Crosby, 1996).

Based on our results, the most important quality practices are employee relations, training, role of top management, and data and reporting. Hence, companies should focus on developing formal reward and recognition systems to encourage employee involvement, support teamwork, and provide feedback to the employees. At the same time, they should invest in developing their managers to fully reap the benefits from quality implementation. In addition, in healthcare industry, a strong leadership that must be started by the top management effects the successes of TQM applications. Quality improvement plans recommended by several experts underline primarily the commitment of top management. Managers will require information to create business intelligence, which necessitates data collection and analysis of current processes and customer needs.

The success of TQM increases as it spreads throughout the company. The philosophy of doing things right should be applied with enthusiasm and commitment throughout the organization - from top to bottom and the little steps forward (called "Kaizen" by the Japanese) must be viewed as "a race without a finish". As a result, the effective use of TQM is a valuable asset in a company's resource portfolio. It can produce significant competitive talent and be a source of competitive advantage.

We are aware of several limitations and hence opportunities for further research of this study. First, sample size is barely sufficient and needs to be increased. The sample size of 50 posed some estimation problems with regard to degrees of freedom in the operationalization process of total quality management block and testing the path model. Therefore, summated scales were used for each component of TQM. We plan to increase our sample size in the future by extending the data collection effort to several largest cities in Turkey. Second, we employed subjective evaluations of the hospitals' top managers only, and we believe objective performance indicators should also be employed. Finally, other estimation methods, such as neural networks, can provide additional insights in the future. 
Journal of Global Strategic Management | V. 12 | N. 1 | 2018-June | isma.info | 067-080 | DOI: 10.20460/JGSM.2018.262 Appendix A

\section{Role of Top Management and Quality Policy.}

1. Extent to which top executives assume responsibility for quality performance.

2. Acceptance of responsibility for quality by major department heads.

3. Degree to which top management (top executive and major department heads) is evaluated for quality performance.

4. Extent to which top management supports a long- term quality improvement process.

5. Extent to which the top management has objectives (Management By Objectives) for quality performance.

6. Importance attached to quality by top management in relation to cost/revenue objectives.

7. Degree to which top management considers quality improvement as a way to increase profits.

8. Degree of comprehensiveness of the quality plan.

9. Extent to which top management has developed and communicated a Vision for Quality as part of a Strategic Vision of the Organization.

\section{Training.}

1. Specific work skills training given to hourly employees

2. Training in statistical techniques in the hospital as a whole

3. Training in advance statistical techniques in hospital as a whole

4. Extent to which quality improvement teams are trained in problem solving approach

\section{Product / Service Design.}

1. Thoroughness of new product design reviews before the product is produced and marketed

2. Coordination among affected departments in the product development process

3. Quality of new product emphasized in relation to cost objectives

4. Quality emphasis by customer service, marketing and PR personnel

5. Use of patient focused hospital concept

\section{Supplier Quality Management.}


Journal of Global Strategic Management | V. 12 | N. 1 | 2018-June | isma.info | 067-080 | DOI: 10.20460/JGSM.2018.262

1. Extent to which suppliers are selected based on quality rather than price or delivery schedule

2. Involvement of the suppliers in the product development process

3. Extent to which longer term relationships are offered to suppliers

4. Clarity of specifications provided to suppliers.

\section{Process Management/Operating Procedures.}

1. Use of statistical control charts to control processes.

2. Amount of preventive equipment maintenance.

3. Amount of inspection, review or checking of work.

4. Importance of inspection, review or checking of work.

5. Stability of work schedules.

6. Clarity of work or process instructions given to employees.

\section{Quality Data and Reporting.}

1. Availability of cost of quality data in the hospital.

2. Availability of quality data (mortality and morbidity, etc.).

3. Timeliness of quality data.

4. Extent to which quality data (cost of quality, mortality and morbidity, errors, etc.) are used as tools to manage quality.

5. Extent to which quality data are available to managers and supervisors.

6. Extent to which quality data are used to evaluate supervisor and managerial performance.

7. Extent to which quality data, control charts, etc. are displayed in work areas.

8. Scope of the quality data includes clinical performance and service/process performance.

\section{Employee Relations.}

1. Extent to which employee involvement type programs are implemented in the hospital.

2. Effectiveness of quality teams or employee involvement type programs in the hospital.

3. Extent to which the employees are held responsible for error free output.

4. Amount of feedback provided to the employees on their quality performance. 
Journal of Global Strategic Management | V. 12 | N. 1 | 2018-June | isma.info | 067-080 | DOI: 10.20460/JGSM.2018.262

5. Degree of participation in quality decisions by hourly/non-supervisory employees.

6. Extent to which quality awareness building among employees is on going.

7. Extent to which employees are recognized for superior quality performance.

\section{Appendix $B$}

\section{Non-Financial Performance.}

1. Service quality as perceived by customers.

2. Market share gain over the last three years.

3. Reputation among major customer segments.

4. Capacity to develop a unique competitive profile.

5. New product/service development.

6. Market development.

7. Market Orientation.

\section{Financial Performance.}

1. Revenue growth over the last three years.

2. Net profits.

3. Return on investment.

4. Profit to revenue ratio.

5. Cash flow from operations.

6. Share of net patient revenue

\section{Appendix $C$}

Index values for the latent variables are calculated as follows:

PerfInd $=\frac{E[\eta]-\operatorname{Min}[\eta]}{\operatorname{Max}[\eta]-\operatorname{Min}[\eta]} .100$

Where, $E[\eta], \operatorname{Min}[\eta]$ and $\operatorname{Max}[\eta]$ denote the expected, the minimum and maximum value of the latent variable respectively.

$$
\begin{aligned}
& \operatorname{Min}\left[\eta_{j}\right]=\sum w_{j h} \operatorname{Min}\left[x_{j h}\right] \\
& \operatorname{Max}\left[\eta_{j}\right]=\sum w_{j h} \operatorname{Max}\left[x_{j h}\right]
\end{aligned}
$$




\section{Journal of Global Strategic Management | V. 12 | N. 1 | 2018-June | isma.info | 067-080 | DOI: 10.20460/JGSM.2018.262 REFERENCES}

Ahire, S.L., Golhar, D.Y. and Waller, M.A. (1996). "Development and Validation of TQM Implementation Constructs", Decision Sciences, 27: 23-56.

Albaum, G., Strandskov, J., Duerr, E. (2002). International Marketing And Export Management, PrenticeHall.

Anderson, J.C., Rungtusanatham, M. And Schroeder RG. (1994). “A Theory Of Quality Management Underlying The Deming Management Method”, Academy of Management Review, 19: 472-509.

Bates, K., Bates, H. and Johnston, R. (2003). "Linking Service to Profit: The Business Case for Service Excellence", International Journal of Service Industry Management, 14 :173-183.

Benson, G.P., Saraph, J.V. and Schroeder, R.G. (1991). "The Effects of Organizational Context on Quality Management: An Empirical Investigation”, Management Science 37: 1107-1124.

Black, S.E. and Porter, L.J. (1996). "Identification of the Critical Factors of TQM", Decision Sciences, 27: 1-21.

Butler, T.W. and Leong, G.K. (2000). "The Impact of Operations Competitive Priorities on Hospital Performance", Health Care Management Science, 3: 227-235.

Camison C. (1996). "Total Quality Management in Hospitality: An Application of the EFQM Model", Tourism Management, 17: 191-201.

Chin, W.W. (1998). "The partial least squares approach for structural equation modeling", in Marcoulides, G.A. (Ed.), Modern Methods for Business Research. Lawrence Erlbaum Associates. London.

Crosby, P.B. (1996). Quality is free. McGraw-Hill.

Deming, W.E. (1986). Out of the Crisis. MIT Center for Advanced Engineering Study, Cambridge, MA.

Eggli, Y. and Halfon, P. (2003). “A Conceptual Framework for Hospital Quality Management”, International Journal of Health Care Quality Assurance, 16: 29-36.

Flynn, B.B. and Saladin, B. (2001). "Further Evidence on the Validity of the Theoretical Models Underlying the Baldrige Criteria”, Journal of Operations Management, 19: 617-652.

Flyyn, B.B., Schroder, R.G. and Sakakibara, S. (1994). "A Framework for Quality Management Research and an Associated Measurement Instrument", Measurement Instrument. Journal of Operations Management, 11: 339-366.

Flyyn, B.B., Schroeder, R.G. and Sakakibara, S. (1995). "The Impact of Quality Management Practices on Performance and competitive Advantage”, Decision Sciences; 26: 659-691.

Fornell, C., Cha, J. (1994). "Partial least squares", in Bagozzi, R.P. (Ed.), Advanced Methods of Marketing Research. Cambridge: Basil Blackwell.

Franklin, C.J. (1997). "Industry output and employment projections to 2006 (Employment outlook: 1996 - 2006)”, Monthly Labor Review; page: 120: 39.

Fynes, B. and Voss, C. (2001). "A Path Analytic Model of Quality Practices, Quality Performance, And Business Performance”, Production and Operations Management 10:494-513.

Gadenne, D. and Sharma, B. (2002). “An Inter-Industry Comparison of Quality Management Practices and Performance", Managing Service Quality, 12: 394-404.

Hansson, J. and Eriksson, H. (2002). "The Impact of TQM on Financial Performance", Measuring Business Excellence, 6: 44-54.

Jacob, R., Madu, C.N. and Tang C. (2004). "An empirical assessment of the financial performance of Malcolm Baldrige Award winners", International Journal of Quality and Reliability Management, 21: 897-914.

Kanji, G.K. and Wallace, W. (2000). "Business Excellence through Customer Satisfaction", Total Quality Management, 11: 979-998. 
Kaplan, R.S. and Norton, D.P. (1996). The balanced scorecard: Translating strategy into action. Boston: Harvard Business Scholl Press.

Kenagy, J.W., Berwick, D.M. and Shore, M.F. (1999). "Service Quality in Health Care", The Journal of American Medical Association, 28: 661-668.

Kunst, P. and Lemmink, J. (2000). "Quality Management and Business Performance in Hospitals: A Search for Success Parameters", Total Quality Management, 11: 1123-1133.

Kurt, A., \& Zehir, C. (2016). The Relationship Between Cost Leadership Strategy, Total Quality Management Applications And Financial Performance . Doğuş Üniversitesi Dergisi, 97-110.

Li L. (1997). "Relations between Determinants of Hospital Quality Management and Service Quality Performance: A Path Analytic Model", International Journal of Management Science, 25:.535-545.

Lim, P.C. and Tang, N.K.H. (2000). "The development of a model for total quality healthcare", Managing Service Quality, 10: 103-111.

LohmLoller, J.B. (1989). Latent Variables Path Modeling with Partial Least Squares. Physica-Verlag, Heildelberg.

Madu, C.N., Kuei, C.H. and Jacob, R.A. (1996), “An Empirical Assessment of the Influence of Quality Dimensions on Organizational Performance", Internal Journal of Production Research, 34: 1943-1962.

McAlexander, J.H., Keldenberg, D.O. and Koenig, H.F. (1994). “Service Quality Measurement”, Journal of Health Care Marketing, 14: 34-39.

Mulaik, S.A. (1972). The Foundations of Factor Analysis, New York: McGraw-Hill.

Nunnaly J. (1978). Psychometric Theory, New York: McGraw-Hill.

Nwabueze, U. and Kanji, G.K. (1997), “A System Management Approach for Business Process ReEngineering”, Total Quality Management, 8: 281-292

Powel, T.C. (1995). "Total quality management as competitive advantage", Strategic Management Journal, 16:15-37.

Raju, P.S. and Lonial, S.C. (2002). "The Impact of Service Quality and Marketing on Financial Performance in the Hospital Industry: An Empirical Examination", Journal of Retailing and Consumer Services, 9: 335-348.

Sadikoglu, E., \& Zehir, C. (2010). Investigating the Effects of Innovation and Employee Performance on the relationship between Total Quality Management Practices and Firm Performance: An Empirical Study of Turkish Firms. Int. J.Production Economics,127:1:13-26.

Samson, D. and Terziovski, M. (1998). "The Relationship between Total Quality Management Practices and Operational Performance", Journal of Operations Management, 17: 393-409.

Saraph, JV, Benson, G.P. and Schroder, R.G. (1989). "An Instrument for Measuring The Critical Factors of Quality” Management. Decision_Science, 20: 810-829.

Tenenhaus, M., Vinzi, V.E. and Chatelin, Y.M. (2005). "PLS path modeling", Computational Statistics and Data Analysis, 48: 159-205.

Tenenhaus, M. (2004). "PLS Regression and PLS Path Modeling for Multiple Table Analysis", COMPSTAT Proceedings, Berlin: Physica-Verlag Springer.

Venkatraman, N. (1989). "Strategic Orientation and Business Enterprises: the Construct, Dimensionality, and Measurement." Management Science, 35: 942-962.

Wilson, D.D. and Collier, D.A. (2000). "An Empirical Investigation of the Malcolm Baldrige National Quality Award Causal Model”, Decision Sciences, 31: 361-390.

Wold, H. (1973). "Non-linear iterative partial least squares (NIPALS) modeling. Some current developments", in Krishnaiah, P.R. (Ed.), Multivariate Analysis. NY: Academic Press.

Wold, H. (1985). "Partial least squares", in Kotz, S., Johnson, N.L. (Eds.), Encyclopedia of Statistical Sciences, NY: Wiley. 
Journal of Global Strategic Management | V. 12 | N. 1 | 2018-June | isma.info | 067-080 | DOI: 10.20460/JGSM.2018.262

Wold, H. (1975). "Soft modelling by latent variables: the non-linear iterative partial least squares (NIPALS) approach", in Gani, J. (Ed.), Perspectives in Probability and Statistics: Papers in Honour of MS Bartlett on the Occasion of his Sixty-8fth Birthday. Applied Probability Trust, London: Academic.

Wujiabudula , A., \& Zehir, C. (2016). The Effects Of Organizational Learning On Firm Performance Through Product Innovation . Journal of Global Strategic Management ,10:1: 79-88.

Yang, C.C. (2003). "The Establishment of a TQM System for the Health Care Industry", The TQM Magazine, 15: 93-98.

Yasin, M.M., Meacham, K.A. and Alavi, J (1998). “The Status of TQM in Healthcare”, Health Marketing Quarterly, 15: 61-84.

Yavas, U., Bilgin, B. and Shemwell, D.J. (1997). "Service quality in the banking sector in an emerging economy: a consumer survey", International Journal of Bank Marketing; 15: 217-223.

Zabada, C., Asubonteng, R. and Munchus, G. (1998). "Obstacles to the Application of Total Quality Management in health Care Organizations", Total Quality Management, 9: 57-66.

Zairi, M. and Youssef, M.A. (1995). "Benchmarking critical factors for TQM PartI: theory and foundations", Benchmarking for Quality Management and Technology, 2: 5-20.

Zehir, S., (2016). How Competitive Strategies, Change Management Applications, And Information System Influence Firm Performance, Journal of Global Strategic Management, 10;1;67-77. 